\title{
NOTES
}

\section{Purity and Utility: Diversity of Interest in River Pollution}

It has recently been said that "the American people must destroy water pollution or it will destroy us." I While one may indulge the hope that such a ringing challenge will prove effective as a battle-cry, yet until one or the other of these all-decisive alternatives is forthcoming, it seems safe to predict that the fate of the nation's streams and of the people's interests therein will continue to hang by the more or less firm thread of judicial decision, under the same body of law that governed when Pepys and his neighbor complained of the dumping of garbage in the Thames. In the succeeding two and a half centuries the clashing demands of an industrial and metropolitan civilization have made the problem of river pollution, in both its legal and economic aspects, increasingly more complex. But even this interplay of opposing interests in utilizing the full advantages of flowing water has long since lost its novelty; these interests have increased rather in number and extent than in kind since their creation by the commencement of industrial development and urban concentration. ${ }^{2}$

Fraught with vital social concern, the legal problems arising out of the fact that a great many persons are attempting to employ a limited amount of water for an unlimited number of purposes constantly compel the judiciary to adapt established principles of law to the shifting economic scene. ${ }^{3}$ Accordingly, in this field of the law perhaps more than in any other, it is not always proper to conclude, simply because one court approves a certain form of conduct and another court in a different locality, while recognizing the same rule of law, forbids similar conduct, that therefore one court is right and the other wrong. It may well be justifiable, for instance, for one court to enjoin an upper riparian owner from fouling a stream with house refuse in such a way as to make it unfit for a lower proprietor to raise trout therein, ${ }^{4}$ while another court refuses to enjoin the drainage of water from gravel pits merely to enable a lower owner to grow watercresses. ${ }^{5}$ Again, it may be proper to restrain the pollution of a stream forming a part of a city's water supply by the overflow from a duck pond, ${ }^{6}$ while elsewhere circumstances prompt a holding that some pollution of a

I. Hon. Augustine Lonergan, United States Senator from Connecticut, Stream Pollution in the United States, quoting Dr. Theobald Smith (radio address, Dec. 23, I935).

2. "In the Cart are found perch, trout, flounders, and braises, or gilt-heads, but none of them in any considerable quantities, owing, no doubt, in a great degree to the bleach-fields, print-fields, and a copperas work upon the banks of the river. As for the fine large pearis once found in this river, and which, according to our old historians, had been noticed by the most eminent jewelers in Europe, they have long disappeared, and the river has become a more certain source of wealth by its utility to an industrious and manufacturing neighbourhood." Statistical Account of Scotland relating to the Abbey Parish of Paisley (1793), quoted in Taylor, The Laze Affecting River Pollution (1927) I Scots. L. T. I25.

3. Cf. Heilman, The Correlation Between the Sciences of Law and Economics (1932) 20

CaltF. L. Rev. 379, 38I.

4. Seaman v. Lee, io Hun 607 (N. Y. I877).

5. Weeks v. Heward, Io Week. Rep. 557 (Ch. I862).

6. New York v. Blum, 208 N. Y. 237, I0r N. E. 869 (1913), affirming 15I App. Div. 923, I35 N. Y. Supp. I I04 (rgI2), modifying 72 N. Y. Misc 243, I3I N. Y. Supp. 87 (I9rI). 
stream by the defendant's use of his pond for horses, cows, and geese is within his right as being only a reasonable use. ${ }^{7}$ And such questions as where lies "the dividing line between a reasonable and an unreasonable quantity of slimes and tailings to discharge into the stream" may well prove elusive for any court to answer. ${ }^{8}$

Fortunately, in the common-law doctrine of riparian rights the courts have a conveniently flexible legal yardstick. While the water flowing in a natural stream is not subject to ownership, ${ }^{9}$ the owner of riparian land is said to have a right to the continued flow of the stream without substantial diminution in quantity or substantial alteration in quality, with a corresponding duty to refrain from interfering with the flow to more than a reasonable extent. ${ }^{10}$ In short, the riparian right is a qualified right, a right to enjoy all uses of the stream that are not unreasonable in their effect on other riparian owners. It is not a right to have the stream flow as it was wont to flow, but only as it may from time to time be somewhat diminished or polluted by another riparian owner's reasonable use. ${ }^{11}$

While some of the states of the Far West ${ }^{12}$ have rejected the common-law doctrine of riparian rights in favor of the prior appropriation rule, which rests on an utterly different conception, ${ }^{13}$ curiously enough the legal result in pollution cases-though not in cases of diversion or diminution-is approximately the same as that reached under the traditional riparian right view. This is so because the right obtained by priority to a continued taking of a quantity of water does not include the right to pollute the unappropriated water left in the stream. ${ }^{14}$ California has developed a rather perplexing hybrid system combining both of the rival conceptions aforementioned, with the common-law rule of riparian rights appearing to predominate; ${ }^{15}$ but in adjudicating the right to pollute or to be free from

7. McEvoy v. Taylor, 56 Wash. 357, I05 Pac. 851 (I909).

8. See Wilmore v. Chain O'Mines, Inc., 44 P. (2d) I024, I028 (Colo. I935).

9. Mason v. Hill, 5 B. \& Ald. I (K. B. I833) ; 3 Kent, Commentaries *439.

10. See Dumont v. Kellog, 29 Mich. 420, 424 (1874); Embrey v. Owen, 6 Ex. 353, 369 (I85I); I TIFFANY, REAI PROPERTY (2d ed. I920) II3I. A view that the Michigan cases represent a third doctrine, that of "reasonable use", and that this is not the same as the common-law rule of riparian rights, is expressed in Jacobson, Stream Pollution and Special Interests (1933) 8 WIS. L. REV. 99, I05, but the distinction appears not well founded.

II. See Holmes v. Nay, I86 Cal. 23I, 235, Ig9 Pac. 325, 327 (I92I) ; Merrifield v. Worcester, IIO Mass. 216, 219 (1872) ; I FARNHAM, WATERS (1904) \$ 64; Wiel, Running Water (I909) 22 HARV. L. Rev. 190, 199. To the effect that this is a right incident to the ownership of riparian land and can not be granted to a non-riparian owner as a right in gross, see Stockport Waterworks Co. v. Potter, 3 H. \& C. 300 (Ex. I864); Harvey Realty Co. v. Borough of Wallingford, III Conn. 352, I50 At1. 60 (I930) ; cf. Doremus v. City of Paterson, 63 N. J. Eq. 605, 52 Atl. IIO7. (I902). This proposition does not mean, however, that pollution of a stream by a riparian owner may not invade a right of a non-riparian owner. Masonite Corp. v. Burnham, I64 Miss. 840, I46 So. 292 (1933) (non-riparian awarded damages for nuisance based on increased number of mosquitoes bred in creek due to pollution by defendant).

I2. Arizona, Colorado, Idaho, Montana, Nevada, New Mexico, Utah, Wyoming. See Bingham, Some Suggestions Concerning the California Law of Riparian Rights, in RADIN \& KIDD, LEgal Essays IN TRIBUTE To ORRIN KIPP MCMurRay (I935) 7, 8.

13. See Oppelander v. Left Hand Ditch Co., I8 Colo. I42, 148, 3 I Pac. 854, 856 (I892); Wiel, Theories of Water Law (Igr4) 27 HARv. L. REv. 530.

14. Suffolk Gold Mining \& Milling Co. v. San Miguel Consol. Mining \& Milling Co., 9 Colo. App. 407, 48 Pac. 828 (I897); Wilmore v. Chain O'Mines, Inc., 44 P. (2d) I024 (Colo. I935).

I5. Lux v. Haggin, 69 Cal. 255, 4 Pac. 9rg (I884) ; Miller \& Lux v. Madera Canal \& Irrigation Co., I55 Cal. 59, 99 Pac. 502 (Ig09). This situation has provoked considerable 
pollution the California courts are apparently moved by much the same influences as are others.

In general, it would seem that such right expands or contracts, as a matter of judicial practice, in response to the geographical and economic environment, the identity of the parties before the court, and the interests of the groups represented by them. A survey of the decisions warrants their classification roughly into three groups, according as the predominant interest involved is the industrial demand to pollute streams for the putpose of disposing of mining and manufacturing refuse, the public interest of protecting the purity of the water supply, or the desire of municipalities to have their sewage carried off by the rivers.

Where the parties to a suit are two manufacturers, two miners, a miner and a manufacturer, or even one of these and a farmer, the interests are usually much less clear-cut than in those cases wherein some out-and-out public purpose is apt to make the weight of "utility" decisive. ${ }^{18}$ It is not surprising, then, that it is in the former cases, where the parties stand on an approximately even footing, that the courts are able to examine the legal problem with an unclouded vision; and accordingly, the opinions written in such cases are likely to state most accurately the factors that correctly should be given consideration in determining the bounds of the right to pollute. ${ }^{17}$ These factors are: the size, depth, and velocity of the stream, the quantity and quality of the polluting material, the purpose for which the defendant is polluting the stream, the distance between the plaintiff's premises and the point where the polluting material is discharged, ${ }^{18}$ and the harmful effect on the plaintiff or, even where there is non-user, on the water flowing by his land. ${ }^{19}$

But even in this class of cases, the judges not infrequently indulge a preference for or against some particular interest or activity, ${ }^{20}$ and especially

rivalry among the legal writers championing each view. See Binghàm, op. cit. supra note I2; Grunsky, The Riparian Doctrine in California (1930) 4 CALIF. B. J. I78, 204; Treadwell, Moderniaing the Water Law (I928) I7 CALIF. L. REV. I.

16. $C f$. Jacobson, op. cit. supra note Io, at I22.

17. See Collins Mfg. Co. v. Wickwire Spencer Steel Co., I4 F. (2d) 87r (D. C. Mass. I926) ; Parker v. American Woolen Co., I95 Mass. 59r, 8I N. E. 468 (I907) ; Holsman v. Boiling Spring Bleaching Co., I4 N. J. Eq. 335 (Ch. 1862); Strobel v. Kerr Salt Co., I64 N. Y. 303,58 N. E. I42 (r900).

18. In Strobel v. Kerr Salt Co., 164 N. Y. 303, 58 N. E. I42 (1900), mill owners one and a half to thirty miles below the defendant's salt works were awarded injunctive relief.

I9. Under the traditional common-law theory, the question of the plaintiff's user or nonuser is not a factor to be considered, Mann v. Willey, 5I App. Div. I69, 64 N. Y. Supp. 589 (3d Dep't I900); for a lower riparian proprietor who is not using the water at all may acquire a right of action against an upper riparian for materially altering the quantity or quality of the stream, the theory being-though logically unsupportable-that unless a right of action is given to the lower owner, the upper may acquire a prescriptive right to diminish or pollute the flow of water. See Ulbricht v. Eufaula Water Co., 86 Ala. 587, 6 So. 78 (I888): Stanford v. Felt, 7I Cal. 249, I6 Pac. 900 (I886); Bingham, op. cit. supra note I5, at I5. However, what other riparian owners would ordinarily need for domestic purposes has bearing on the reasonableness of the defendant's user. Gillett v. Johnson, 30 Conn. I80 (I86I); Barrett v. Parsons, Io Cush. 367 (Mass. 1852).

20. See Carhart v. Auburn Gas Light Co., 22 Barb. 297, 312 (N. Y. 1856) ("gas works are to be placed in the class of erections which are not within the ordinary and usual purposes to which real estate is applied") ; McDonough v. Russell-Miller Milling Co., $38 \mathrm{~N}$. D. $465,483,165$ N. W. 504, 509 (1917) ("we are by no means satisfied that a riparian owner . within the limits of a city at a point [close] to residences and manufacturing establishments . . . can legally claim that the cutting of ice ... is a reasonable use of the waters in the stream"). 
is this so where geographical circumstances have made the development of some one natural resource the foundation of the community's economic structure. Mining is certainly the most striking example of such an activity. In California the early entrenchment of the pioneer gold prospectors who were largely responsible for the settlement as well as the development of that state found no one to resist the full satisfaction of their economic demands. And the early decisions of the California Supreme Court seem to have for their only purpose an adjustment between the claims of prior and subsequent appropriators in view of the requirements of the hydraulic process of mining, ${ }^{21}$ without regard to the possible hardships imposed on lower agriculturists by such methods. Very soon, however, the value of fruit-growing became sufficient to merit protection from encroachments by mining: ${ }^{22}$ And it was not long until the necessity for curtailing the destructive results of the hydraulic process by injunction forced itself upon the court. ${ }^{23}$ Of recent years, it is interesting to note, the orange-growers seem to be receiving at least the equal protection of the law to which they are entitled against injury by industrial operations. ${ }^{24}$

The glaring example of an overbalancing of interests in favor of mining is not to be found in California or the "prior appropriation" states, however, but in Pennsylvania, under a curious stretching of the riparian right doctrine whereby the coal mines have since I 886 enjoyed nearly complete liberty in pouring their acidulated waters into the streams of the state. By its decision in the now notorious case of Pennsylvania Coal Co. v. Sanderson, ${ }^{25}$ the Supreme Court of Pennsylvania has limited the application of the maxim sic utere tuo ut alienum non laedas which is generally observed, ${ }^{26}$ in favor of the proposition that harm caused to one landowner by another as the necessary and unavoidable result of a natural use of his land by the latter, without negligence or malice, is dammum absque iniuria. ${ }^{27}$ Though this rule has been strictly limited to a "natural use" of the land ${ }^{28}$ and, in stream

2x. Bear River \& A. Water \& Mining Co. v. New York Mining Co., 8 Cal. 327 (I857); Hill v. King, 8 Cal. 336 ( 1857 ); $c f$. Esmond v. Chew, I5 Cal. I37 (I860); Hill v. Smith, 27 Cal. 476 (I865).

22. Wixon v. Bear River \& A. Water \& Mining Co., 24 Cal. 367 (I864).

23. People v. Gold Run Ditch \& Mining Co., 66 Cal. I38, 4 Pac. Ir52 (1884); Eureka Lake \& Y. Canal Co. v. Superior Ct., 66 Cal. 3II, 5 Pac. 490 (I885); McLaughlin v. Del Re, 7r Cal. 230, 6 Pac. 88I (I886).

24. Cf. California Orange Co. v. Riverside Portland Cement Co., 50 Cal. App. 522, I95 Pac. 694 (1920).

25. II3 Pa. I26, 6 At1. 453 (I886) (mine operator permitted to pollute stream to the damage of plaintiff's country estate). Contra: Drake v. Lady Ensley Co., I02 Ala. 50I, I4 So. 749 (I894); Thomas v. Ohio Coal Co., 199 Ill. App. 50 (I916); Straight v. Hover, 79 Ohio St. 263,87 N. E. I74 (Ig09); and numerous other cases definitely repudiating the Pennsylvania view. See Bohlen, The Rule in Rylands v. Fletcher (I9I0) 59 U. OF PA. L. REv. 298, 373, 388-389, n. 7I; Note (I924) 73 U. OF PA. L. Rev. 66, 68.

26. See Holmes v. Nay, I86 Cal. 23I, 24I, I99 Pac. 325, 330 (I92I). And previous Pennsylvania decisions indicated that the necessities of one man's business were not to be made the standard of another's rights. See Wheatley v. Chrisman, $24 \mathrm{~Pa}$. 298, 302 (I855); Pennsylvania R. R. v. Miller, Ir2 Pa. 34, 4I, 3 Atl. 780, 78I (I886); cf. Howell v. McCoy, 3 Rawle 256, 269 ( 1832 ).

27. The following cases applied the rule of the Sanderson case in related situations: Harvey v. Susquehanna Coal Co., 20I Pa. 63, 50 Atl. 770 (rgo2) ; Alexander v. Wilkes-Barre Coal Co., $254 \mathrm{~Pa}$. I, 98 Atl. 794 (I916).

28. Robb v. Carnegie Bros., I45 Pa. 324, 22 Atl. 649 (189I) ; Hauck v. Pipe Line Co., I53 Pa. 366, 26 Atl. 644 (I893); Conti v. New Castle Lime \& Stone Co., 94 Pa. Super. 32 I (1928). 
pollution cases, to the discharge of water by the natural drainage of the land, ${ }^{29}$ it still gives a surprising privilege to coal mining and probably to stone quarrying ${ }^{30}$ and oil-producing ${ }^{31}$ as well. Indeed, for a time it seemed possible that even the public interest in protecting the water supply was to be subordinated, ${ }^{32}$ but finally the Pennsylvania court came to the point of expressly recognizing that the public health might be of more compelling importance than the prosperity of a great industry, and it refused to extend the special privilege given in the Sanderson Case to include any right to drain polluted mine water into a natural stream to the injury of the public water supply. ${ }^{33}$

There can no longer be any doubt that the public drinking supply, in its essential importance to the common welfare, dwarfs all other interests in the use of flowing water. And everywhere this matter is hedged about with a protective growth of statutes. ${ }^{34}$ Yet statutory regulation in the interest of the public health by no means disposes of all problems-it rather tends to complicate them. For, while the state may under its police power and by reasonable methods regulate and restrain certain uses of a stream in the interest of the general welfare, ${ }^{35}$ yet it may not, under the federal ${ }^{36}$ and most state constitutions, ${ }^{37}$ go so far as to deprive the landowner of the enjoyment of his rights of private property without just compensation. ${ }^{38}$ On the other hand, by condemnation and compensation under the power of eminent domain, a state or its instrumentality may do what would not be possible under its police power. ${ }^{39}$ It is not within the purpose of the present note to discuss these questions of constitutional law, except to point out that in general the courts are astute to uphold regulatory statutes and ordinances, regarding the conservation of the public water supply as being peculiarly within the state's police power. ${ }^{40}$

Parallel, though distinct, problems arise under legislative control of municipal sewage, ${ }^{41}$ the difference being that which lies between statutory

29. McCune v. Pittsburgh \& Baltimore Coal Co., $238 \mathrm{~Pa} .83$, 85 Atl. Iro2 (I9I3).

30. See Conti v. New Castle Lime \& Stone Co., 94 Pa. Super. 321 (I928).

3I. See Hauck v. Pipe Line Co., I53 Pa. 366, 26 At1. 644 (1893).

32. Union Water Co. v. Enterprise Oil Co., 38 Pitts. L. J. I59 (I890) (refused to enjoin oil producer from discharging salt water into stream used as drinking supply).

33. Pennsylvania R. R. v. Sagamore Coal Co., 28I Pa. 233, 126 At1. 386 (rg24), cert. denied, 267 U. S. 592 (I925); see Commonwealth exr rel. Att'y Gen. v. Russell, I72 Pa. 506, 509, 33 Atl. 709, 710 (1896).

34. E. g., Ilu. Rev. Stat. (Cahill, I933) c. 19, § I44 (I) ; Ind. Stat. Ann. (Baldwin, 1934) \$\$ 84I0-843I; PA. STAT. ANN. (Purdon, I930) tit. $35, \$ \$ 68 I-684$ ("this act shall not apply to any pollution or contamination caused by or resulting from water pumped or flowing from coal mines or water used in the preparation of coal"); UTAH REv. STAT. (I933) $\S$ I5-8-15.

35. California-Oregon Power Co. v. Beaver Portland Co., 73 F. (2d) 555 (C. C. A. 9th, 1934); cf. Nebbia v. New York, 29 I U. S. 502 (1934).

36. U. S. Const. Amend. XIV, § I.

37. E. g., ILI. Const. art. II, § I3; Missourt Const. art. II, §§ 20, 21 ; UTAH Const. art. I, $\$ \S 7,22$.

38. Irving's Ex'rs v. Media, I94 Pa. 648, 45 Atl. 482 (1900) ; Bountiful City v. De Luca, 77 Utah I07, 292 Pac. 194 (1930).

39. See Bountiful City v. De Luca, 77 Utah I07, I24, 292 Pac. I94, 201 (I930).

40. State ex rel. Dep't of Health v. Chemical Co. of America, 9o N. J. Eq. 425, I07 At1. I64 (Ch. I9I9) ; North Carolina State Board of Health v. Commissioners of Louisburg, I73 N. C. 250, 9I S. E. IoIg (IgI7); Commonwealth v. Emmers, 22I Pa. 299, 70 Atl. 762 (I908). 4I. E. g., Conn. Gen. Stat. (I930) c. I40; Ill. Rev. Stat. (Cahill, I933) c. 42, \$323; Ind. Stat. AnN. (Baldwin, I934) §\$ II534-II536, II558-II56I; MASS. GEN. LAws (I932) c. 83 ; Pa. Stat. AnN. (Purdon, 1930) tit. $35, \$ \S 741-750$. 
prohibition of the full exercise of a property right of private individuals interfering with the public water supply and statutory authorization of a more than full exercise of the property right to which a municipality would be entitled as a riparian owner. ${ }^{42}$ The riparian right to the reasonable use of a stream is a right of private property, ${ }^{43}$ which may not be seized without due process of law or under legislative enactment without compensation being made. ${ }^{44}$ This would seem to mean that not only can the riparian owner's right to use the stream for reasonable purposes not be arbitrarily taken away by a statute attempting to forbid all pollution of the water, but neither can he be deprived (by any statutory authorization of the discharge of sewage by a municipal corporation) of his right to enjoy a reasonable purity of the water. ${ }^{45}$

While there is clearly a certain degree of utility in having a convenient and relatively inexpensive method of disposing of sewage, the courts are not inclined to regard the argument of public necessity very seriously.46 And in view of the direct opposition of such an interest to the overbalancing utility in preserving the purity of the public drinking water, no other attitude could be desirable. Though both are public uses, they are mutually antagonistic, and the more important must prevail. 47 In general most courts uphold the view that the legislature will not be presumed to have authorized what amounts to a nuisance, and consequently pollution by municipalities is actionable or subject to injunction on the same principles that apply to private individuals, the fact that the sewer system producing it has been constructed by public authority being no defense. ${ }^{48}$

The "public necessity" argument, however, has found one sponsor in the Indiana judiciary. In that state, municipalities are allowed to pollute streams so long as they do so by properly constructed sewer systems, ${ }^{49}$ the

42. Though there is considerable disagreement among the authorities, it has been held that a municipal corporation has the right as a riparian proprietor to use the water in the stream on which it is located. City of Canton v. Shock, 66 Ohio St. I9, 63 N. E. 600 (I902). But see City of Emporia v. Soden, 25 Kan. 588, 606 (I88I).

43. Western N. Y. Water Co. v. City of Niagara Falls, 9 I N. Y. Misc. 73, I54 N. Y. Supp. I046 (Sup. Ct. I9I5); see Commonwealth v. Emmers, 221 Pa. 299, 304, 70 At1. 762, 765 ( 1908$)$.

44. Standen v, New Rochelle Water Co., 9r App. Div. 272, 36 N. Y. Supp. 92 (I895); City of Fairbury v. Fairbury Mill \& Elev. Co., I23 Neb. 588, 243 N. W. 774 (I932).

45. City of Waterbury v. Platt Bros. \& Co., 76 Conn. 447, 56 Atl. 856 (Ig04); Western N. Y. Water Co. v. City of Niagara Falls, 91 N. Y. Misc. 73, I54 N. Y. Supp. I046 (Sup. Ct. I9I5).

46. Donnelly Brick Co. v. City of New Britain, I06 Conn. I6\%, I37 Atl. 745 (I927); Barrington Hills Country Club v. Village of Barrington, 357 Ill. II, I9I N. E. 239 (1934).

47. For instance, in Philadelphia, which pours $150,000,000$ to $200,000,000$ gallons of sewage into the Delaware River daily the City Council has been notified by the chairman of the State Sanitary Water Board that after March 3Ist the city will no longer be allowed to discharge into the Delaware or Schuylkill, in view of the "intolerable pollution of the waters of the State." (See Philadelphia Evening Bulletin, Dec. 5, 1935, p. 2.) The fact that the 1936 budget includes no appropriation for a new disposal program will probably not relieve the city of its obligation. See Dep't of Health v. City of North Wildwood, 95 N. J. Eq. 442, 122 Atl. 89I (Ch. I923) (in proceeding by state health department to compel city to cease pollution of the waters of the state and to provide proper means for disposal of its sewage, the fact that the city's bonded indebtedness already equalled the statutory limit held no defense).

48. Southern New England Ice Co. v. Town of West Hartford, Ir4 Conn. 496, I59 At1. 470 (I932); Sammons v. City of Gloversville, 175 N. Y. 346,67 N. E. 622 (I903); Mitchell Realty Co. v. City of West Allis, I84 Wis. 352 , I99 N. W. 390 (I924).

49. City of Richmond v. Test, I8 Ind. App. 482,48 N. E. 610 (1897) ; City of Valparaiso v. Hagen, I53 Ind. 337, 54 N. E. 1062 (1899). 
theory being that in such case there is no taking of property but merely consequential injury which, as the city is not held accountable in the absence of negligence, is dammum absque iniuria. ${ }^{50}$ Although not yet actually repudiated, the fallacy in the economic argument that the welfare of the inhabitants of municipalities demands a special privilege in sewage disposal has been pointed out by a member of the very court which sponsors it: necessity requires rather that the drinking supply be pure than that sewage disposal be inexpensive. ${ }^{51}$ And later cases have either expressly avoided the need for considering the rule ${ }^{52}$ or have cast doubt upon its soundness while making every effort to find the municipality chargeable with negligence thereunder. ${ }^{53}$

Indiana's gradual retraction of its unorthodox conception of social economics apparently leaves Massachusetts as the stanchest defender of cheap municipal sewage systems. In that state, the doctrine that a municipal corporation possesses sufficient attributes of sovereignty to clothe it with a degree of immunity is aided by an ingenious application of the rules of agency and negligence law to reach the result that a city may foul a stream as much as it desires so long as its agents who do the actual work take pains to foul it carefully! 54

Frequently pollution cases take the form of an action at law for a nuisance, that is, for a continuous and unreasonable interference with the plaintiff's enjoyment of his land.55 As the reasonableness of the defendant's use of the stream under his riparian right forms the issue, it is tempting to employ a technique analogous to that used in the common run of negligence cases, wherein the merit of the defendant's conduct is determined by the standard of the reasonably prudent man. However, the impropriety of drawing the issue in pollution cases solely on the basis of whether or not the defendant's fouling of the stream occurs as the result of his negligent conduct in the pursuit of some activity on his land and of freeing him of liability whenever the pollution is the necessary and unavoidable consequence of a natural and careful use of his land has been clearly recognized. ${ }^{56}$ While a

50. That this formula is only the legal clothing of the court's conception of public economic interest is indicated by the fact that the same theory is not applied in cases of pollution by industrial corporations. Weston Paper Co. v. Pope, I55 Ind. 394, 57 N. E. 7I9 (I900) ; of. Barnard v. Shirley, I35 Ind. 547, 559, 34 N. E. 600, 604 (I893) ("Must it be that one who lives on the lower lands on the banks of a stream shall forbid forever the founding of a city on the lands above, forbid the grading streets, the building of sewers, the erection of mills, factories, hospitals, or other means of livelihood, comfort and convenience of the inhabitants?").

5I. Myers, J., in Penn American Plate Glass Co. v. Schwinn, I77 Ind. 645, 658, 98 N. E. 715,720 (I9I2).

52. See Zabst v. City of Angola, 99 Ind. App. III, II4, I90 N. E. 89I, 892 (1934).

53. See City of Frankfort v. Slipher, 88 Ind. App. 356, 365, I62 N. E. 24I, 243 (1928).

54. See Merrifield v. City of Worcester, I Io Mass. 2I6, 22I (I872) ("This exemption of municipal bodies and their officers from liability, and corresponding subordination of individual rights and interests to the safety, health and welfare of the general public, is a principle of frequent application.") ; Anglim v. City of Brockton, 278 Mass. 90, 99, I79 N. E. 289, 293 (1932).

55. This, of course, excludes that class of actions wherein the plaintiff, although his enjoyment is not at all interfered with, is awarded nominal damages on the theory that unless such right of action is given the upper riparian will acquire a prescriptive right. Watson v. New Milford, 72 Conn. $56 \mathrm{~T}, 45$ Atl. I67 (I900); see sipra note I8.

56. Bunker Hill \& Sullivan Min. \& Con. Co. v. Polak, 7 F. (2d) 583 (C. C. A. gth, I925) ; Hunze v. City of Cape Girardeau, 43 S. W. (2d) 882 (Mo. App. I93I) ; Straight v. Hover, 79 Ohio St. 263, 87 N. E. I74 (I909). Contra: Penna. Coal Co. v. Sanderson, II3 Pa. I26, 6 Atl. 453 (1886). C $f$. Verland Oil \& Gas Co. v. Walker, Ioo Okla. 258, 229 Pac. 
certain similarity in terms that is misleading may sometimes be found in the two classes of cases, the legal approach is distinctly different in each. The reasonableness of the upper riparian polluter's use is not measured by any foreseeable risk of probable harm ensuing to the lower riparian; it is rather a question of the reasonableness or unreasonableness in character and extent of the harm which actually does befall the plaintiff as a consequence of a use which may have embodied the highest degree of care. ${ }^{57}$ When liability is imposed for pollution it is likely to be "liability without fault."

Even in the field of negligence the scope of liability is being widened by an enlightened application of principles of utility. ${ }^{58}$ In the field of."liability without fault", where burdens and benefits are apportioned with regard to the maintenance of economic and social equilibrium rather than as a result of opprobrious conduct, and where such matters as the non-negligent pollution of streams really amount to problems in what Professor Harper has aptly termed "social engineering", ${ }^{50}$ it is even more imperative to measure legal accountability by public value.

Ultimately, the questions of "right" and "wrong" must always be decided by reference to community standards and requirements-social, economic, and moral-in short, by reference to a shifting utility. And this should be true whether the "wrong" is to be restrained by injunction or only made the basis for compensation in damages. But with the right once thus defined, it would seem to be both unnecessary and unjust to weigh the particular economic burden expectable in a given case as a basis' for awarding or denying a remedy. Such philosophy may well be the foundation of equity's repeated refusals to "balance the conveniences" in determining whether an injunction is to issue against a nuisance: ${ }^{60}$ On the other hand, the greater flexibility of remedial procedure in equity than at law makes it possible, as well as desirable in many cases, to refuse specific relief in spite

235 (1924) (under statute providing no inflammable product from any oil or gas well shall be permitted to run into any stream tused for watering stock, held negligence per se for defendant to permit oil and salt water to flow into such stream). As to a class of nuisances the essence of which is negligence, however, see opinion of Cardozo, C. J., in McFarlane v. Niagara Falls, 247 N. Y. 340, I60 N. E. 39I (Ig28).

57. See HARPER, TORTS (I933) \$ I82. There also seems to be, in such cases, somewhat of an overlapping of the conception of reasonable use of the stream under the law of riparian rights and the conception of an unreasonable disturbance of the plaintiff's enjoyment which forms the basis of a cause of action for a nuisance. However, the distinction is hardly possible in practice, and common sense clearly demands that the compartmentalism of the law be disregarded in this instance.

58. "The law measures the risks that a man may legitimately take by measuring the value of the interests furthered by his conduct." Cardozo, THE Paradoxes of Legar SCIENCE (I928) 74 .

"It is entirely natural that courts in highly industrialized states, in which the whole tone of public opinion is favorable to the removal of every bar to effective production, should tend to regard it as unreasonable to demand of industry any precautions which might check intensive production by making it unprofitable. On the other hand, in agricultural states it is quite natural that no such regard should be paid to the supposedly harmful economic effect of requiring decent consideration for the interest of the individual's life, limb, and property." Bohlen, Old Phrases and Neze Facts (1935) 83 U. OF PA. L. REv. 305, 306-307.

59. HARPER, TORTS (I933) § I55.

60. See Barrington Hills Country Club v. Village of Barrington, 357 Ill. II, 20, I9r N. E. 239, 243 (1934); Sullivan v. Jones \& Laughlin Steel Co., $208 \mathrm{~Pa}$. 540, 555, 57 Atl. I065, I07I (1904) ("There can be no balancing of conveniences when such balancing involves the preservation of an established right, though possessed by a peasant only to a cottage as his home"). 
of a clear legal right and to leave the complainant to his remedy at law. Essentially a conception of what is "conscionable", ${ }^{61}$ the proposition is most frequently enunciated by saying that equity will not allow its relief to issue where the result would be to place a disproportionate hardship on the defendant. ${ }^{62}$

This conception is one which cuts clearly across the whole field of equity jurisdiction, whether it be in the specific enforcement of a contract, ${ }^{63}$ in relieving a continuing trespass, ${ }^{64}$ or in enjoining a nuisance. ${ }^{65}$ The refusal to balance conveniences, however, appears to be a principle which is limited to the third of these groups - the nuisance cases. Accordingly, it might be somewhat more accurate to say that the principle is a single one: equitable relief will not be awarded where it will produce disproportionate hardship; but in nuisance cases the economic burden imposed on the defendant will usually not be considered such a hardship. The theoretical reason for the stricter rule as to nuisances may well be, as Professor Walsh has suggested, ${ }^{66}$ that in these cases the defendant is chargeable with intending such consequences as are ordinarily brought about by the activity in which he has chosen to engage, whereas in a case of continuing trespass the encroachment is made unwittingly.

At any rate, the very thought of these two coexistent but apparently antagonistic ideas is usually enough to confuse the best of courts; and pollution cases seem unusually capable of inspiring such confusion, probably because a weighing of social values (if not a "balancing of conveniences") is usually so necessary in these cases. Even the Supreme Court of the United States is not entirely free from criticism on this score. For instance, in a recent case the Court's conclusion that the defendant would be subjected to such grossly disproportionate hardship as to justify withholding an injunction was based on the fact that the cost of erecting an auxiliary sewage disposal plant would be $\$ 25,000$, whereas the loss in value of the complainant's land by virtue of the pollution was $\$ 100$ per year. ${ }^{67}$ The better view appears to be that mere monetary considerations should not persuade a denial of equitable relief ; and there is no more reason for a mercenary approach to a case in which one party is a municipality than in a suit between private parties. ${ }^{68}$

On the other hand, some degree of apparent confusion in such cases is certainly inevitable and should properly be regarded as a true indication of the essential nature of the equitable remedy, which issues, not as a matter of

6r. "What may be an entirely tolerable adjustment, when the result is only to award damages for the injury done, may become no better than a means of extortion if the result is absolutely to curtail the defendant's enjoyment of his land." Hand, J., in Smith v. Staso Milling Co., I8 F. (2d) 736, 738 (C. C. A. 2d, I927).

62. See Harrisonville v. Dickey Clay Mfg. Co., 289 U. S. 334, 338 (I933); Att'y Gen. ex rel. Simmons v. City of Paterson, 60 N. J. Eq. 385, 393, 45 Atl. 995, 998 (1900).

63. See Willard v. Taylor, 8 Wall. 557, 567 (U. S. I869).

64. See Hunter v. Carroll, 64 N. H. 572, 573, I5 Atl. I7, I8 (1888).

65. See Bliss v. Anaconda Copper Min. Co., I67 Fed. 342, 365 (C. C. Mont. Igog).

66. See Walsh, Equity (I930) 289.

67. Harrisonville v. Dickey Clay Mfg. Co., 289 U. S. 334 (I933).

68. Cf. Arizona Copper Co. v. Gillespie, Iz Ariz. x90, I00 Pac. 470 (1909), aff'd, 230 U. S. 46 (1913). 
strict right, but of grace. ${ }^{69}$ The chancellor's problem can hardly be described in better words than those of Judge Hunt: ${ }^{70}$

“. . . when there are two citizens, each of whom is engaged in a lawful business, one in mining, the other in farming, and there comes a conflict where neither can enjoy his own property without interfering to some extent with his neighbor in the enjoyment of his, then it is that the problem is presented how to fix the rights of each so as to secure to each the largest measure of liberty possible under all the circumstances of the particular case. Then it is that the court should so frame its decree as to avoid the destruction of the rights of either. . . . Equitable arrangements may often be made when we recognize the principle that, as a philosophic condition of the complexities of society, to some extent men must yield the full enjoyment of certain individual rights."

As intimated in the excerpt just quoted, the supervisory powers of equity are of fundamental importance. And since the conflicting claims confronting a chancellor in stream pollution cases usually require some sort of compromise to reconcile them, it is essential that these powers be liberally used in the framing of decrees, if truly equitable results are to be attained. Generally, the courts are hesitant to issue so flat an injunction as to compel the permanent closing of an industrial plant, though in a few rare and exceptionally clear cases this has been done. ${ }^{71}$ But short of this, the proper extent for a decree has been a matter of considerable difference of opinion. Some courts still insist that the province of injunctive relief is confined to negation and that the means of abating the nuisance must be left to the choice of the defendant. ${ }^{72}$ But fortunately, judicial reluctance to issue a mandatory order seems to be in the minority, the prevailing view being the saner one that the consummation of equity's functions is in decrees which order positive conduct. $^{73}$

The temptation to charge the courts with being the creatures of vested interest has captivated not a few writers, with but specious justification for their carping. While there are certainly glaring exceptions, a fair estimate of the general judicial attitude in the field under discussion leads to the impression that most courts act not only honorably but wisely when they recognize extra-legal influences in a problem which is less a legal than an

69. See Richard's Appeal, $57 \mathrm{~Pa}$. I05 (I868). To the effect that "grace" is not arbitrary and that the chancellor's discretion as to what is conscionable depends, not on his own mere notions, but on community standards of justice and reasonableness, see Walters v. McElroy, I5I Pa. 549, 557, 25 Atl. I25, I27 (I892); Sullivan v. Jones \& Laughlin Steel Co., 208 Pa. 540, 554, 57 Atl. 1065, I07I (1904).

70. In Bliss v. Anaconda Copper Min. Co., 167 Fed. 342, 369 (C. C. Mont. I909).

72. Behnisch v. Cedarburg Dairy Co., I80 Wis. 34, I92 N. W. 447 (Ig23) (decree re-

7I. One such case is Whalen v. Union Bag \& Paper Co., 208 N. Y. I, IOI N. E. 805 quiring defendant to fix its septic tank to comply with public health laws, to flush the creek whenever ordered to do so by the board of health, and to connect up with a sewer then in process of construction held unwarranted).

73. Georgia v. Tennessee Copper Co., 237 U. S. 474 (IgI5) (decree required defendant to keep daily records, appointed a university professor as inspector, and specified that defendant should not permit the escape of gases having a sulphur content of more than 20 tons per day); New York v. Blum, 208 N. Y. 237, Ior N. E. 869 (I9I3) (decree required defendant to allow plaintiff city to clean defendant's duck pond and install a filter at its outlet once a month). 
economic one. Criticism of their inconsistency is easy, when a tribute to their realism would be more deserved.

Although the public as a whole remains apathetic, and there would seem to be few groups (save the Izaak Walton League) possessed of an unqualified desire to see the nation's rivers completely pure, there has been some agitation of late "to do something about river pollution." At present proposals are being formulated, apparently under the sponsorship of Senator Lonergan, for Congressional legislation which would set up a Federal River Pollution Control Board. ${ }^{74}$ While the problem of the fouling of interstate rivers $^{75}$ and the concomitant questions of interstate compacts ${ }^{76}$ and suits between the states in the United States Supreme Court ${ }^{77}$ are as important as they are interesting, yet the great weight of pollution is felt in local waters, and the bulk of reported litigation is between local parties. Some sort of central advisory committee of scientific and economic experts might well prove helpful, but direct control by federal authority seems hardly feasible from either a constitutional or a practical viewpoint. The courts, by combining a frank avowal that the question of "reasonable use" is essentially a matter of utility and public welfare with a readiness to employ the super-. visory powers of equity, can probably do more to insure a sane control of river pollution than can be expected from governing boards or federal commissions.

$$
V . J . R ., J r .
$$

\section{Investments by Fiduciaries in Pennsylvania}

On January 3, I936, the Secretary of Banking reported that over five billions of dollars in trust funds were held by state institutions, primarily trust companies, and nearly a half billion by the trust departments of national banks within the state. ${ }^{1}$ However, these figures indicate only partially the vast importance of fiduciary investments in Pennsylvania, since they do not include a huge, unascertained amount held by private fiduciaries. And the proportion of trust funds is steadily increasing. ${ }^{2}$ Small wonder, then, that the administration of these funds is the subject of frequent legislation and more frequent litigation.

At one time, most trust cases dealt with the existence or creation of a trust. $^{3}$ Today, trust litigation deals primarily with its administration, either in the investment of the res or in the distribution of the proceeds. As regards distribution, the law has been quite thoroughly developed, and, although di-

74. See Ionergan, op. cit. supra note I; cf. Philadelphia Record, Feb. 7, I936, p. I4.

75. See Garner, The Chicago Sanitary District Case (I928) 22 AM. J. INT. L. 837.

76. See (I934) 34 CoL. L. Rev. I69; (I934) 2 GEo. WASH. L. REv, 242.

77. See Missouri v. Illinois, I8o U. S. 208 (I90I); New Jersey v. New York, 283 U. S. 336 (I93I) ; Burch, Conflicting Interests of States over Interstate Waters (1932) Io TENN. L. REV. 267; Kelly, " $A$ River is a Treasure" (1934) 20 AM. B. A. J. 559.

I. $\$ 425,697,284.98$. These figures, compiled as of Nov. I, I935, do not include corporate trusts. 22 DEP'T REP. OF PA. (I936) 30.

2. BUSINESS WEEK, Dec. I4, I935, at 24, 27.

3. It is interesting to note that more than half of Scotr, CASES on TRusts (2d ed. 193I), is devoted to existence of a trust, while only one chapter is devoted to administration, and one section within that chapter to investment by trustees. 
vergent results have been reached by various jurisdictions, the doctrine of Earp's Appeal appears to be immutable in Pennsylvania. ${ }^{4}$ The problems of investment, however, remain vexatious, with the courts and legislatures constantly striving to preserve the principal of the fund and at the same time to procure the largest possible return for the beneficiary, and on the other hand to protect the fiduciary in his choice of investments. ${ }^{5}$ Pennsylvania history shows continual enactment of laws prescribing investments, the primary motive, as in the conservative majority of the states, apparently being conservation of the principal. $^{6}$ The latest attempt to attain this goal, the Fiduciaries Act of July 2, I935, is a broad advancing stride, putting Pennsylvania in the liberal middle group with New York. ${ }^{7}$ Yet, while the new law has the salutary effect of broadening the scope of legal investments and thus according the fiduciary more freedom of choice, it fails to solve numerous existing problems, and raises new ones.

The cases involving trust investments have been numerous, too. As was pointed out in a recent issue of this REviEw, "the trust questions most frequently litigated or in process of adjustment generally involve attempts to surcharge trustees with losses predicated either on investment in non-legal securities or on unauthorized retention of non-legal investments acquired from the estate of the testator or settlor." 8 In such cases, the fiduciary must first show, in order to avoid surcharge, that his investment is valid because of the authority given him by the settlor, the beneficiaries, or the "legal list" of either the common law or statutes. ${ }^{9}$

\section{Due Care and Prudence}

Assuming the type of investment made to be authorized, the particular investment involved must, in addition, have been selected or retained "with

4. For a complete discussion of the Pennsylvania view on distribution, see Note (1935) 83 U. OF PA. L. REv. 773. This problem will not be considered here.

5. As to the purposes of trust investment law, see ig Rep. State Bar Ass's of Wis. (r929) 17,18 .

6. See Hart's Estate (No. I), 203 Pa. 480, 484, 53 At1. 364, 366 (Ig02). For a sketchy history, see pamphlet, TRUST INVESTMENTS IN PA. (1935), published by the Pennsylvania Bankers Association, at 9 et seq. I3-I4.

7. Pa. Stat. Ann. (Purdon, 1935) §80i. See Trust Investments in Pa. (1935)

8. Zoob, Exceptions to the Liabilities of Trustees (I935) 83 U. of PA. L. REv. 726. The question whether an investment is legal, however, may mean other things than "Shall the fiduciary be surcharged?", e. g.: Shall the beneficiary (or estate) be bound by the questioned transaction? Bagnell v. Ives, I84 Fed. 466 (C. C. M. D. Pa. IgrI), where an estate was freed from liability on an unpaid stock subscription balance. Is the other party to the transaction bound? Metzger v. Lehigh Valley Trust and Safe Deposit Co., 220 Pa. 535, 69 Atl. 1037 (I908), held no in a very dubious decision. Shall the trustee be removed? Conyngham's Trust Estate, 9 Lanc. Bar, no. 16 , at 57 (I877) (mere illegal investment insufficient ground). Nevertheless, all except six of nearly one hundred fifty cases studied were efforts to surcharge or otherwise impose liability on the fiduciary for making or continuing an improper investment. In one very interesting case, surcharge was sought for failure to keep a nonlegal investment on the ground that its further retention would have netted a greater profit! In re Scott, 22 D. \& C. 35I (I935). The present note will be confmed mainly to questions of surcharge.

9. "Legal list" and "legal investments" are practically synonymous. Logically, any investment is legal that is upheld by a court. These terms have, however, taken on technical meanings, and include only those investments which statutes, and once the common law, enumerated as those which may be made with impunity.

That the burden of proof is on the fiduciary, primarily because he must account for his funds, is generally recognized. RESTATEMENT, TRUSTS (I935) § I72, Comment b; Kelch's Estate, 2 I D. \& C. 204 (1934). But cf. Macfarlane's Estate, 317 Pa. 377, I77 At1. I2 (1935). 
due care and prudence". Thus, although the settlor had given the trustee discretionary power, the latter was surcharged for investment in bank stock, one of the grounds for surcharge being that the bank had suspended specie payment at the time of investment.10 Similarly, although the "legal list" included obligations of the City of Philadelphia, the Orphans' Court refused to sanction such an investment where the obligation was selling at too high a premium. ${ }^{11}$

But what constitutes due care and prudence? Upon this question, the Pennsylvania decisions have been confusing, though not uniquely so. At first, they seemed clear enough, holding, for example, that the fact that the settlor had invested in certain stock, ${ }^{12}$ or that a prudent man would invest in the stock of a private corporation, ${ }^{13}$ did not of itself relieve the trustee from surcharge. The judges would sanction no hazards with trust funds. A fiduciary was to be a conservator of funds, not an accumulator, and, consequently, was required to take greater care than the ordinary investor.

In later cases appear new and equally vague standards: "negligence", "supine negligence which is required in order to charge a trustee", "gross negligence", "wilful neglect or default". ${ }^{14}$ By I902, however, the Supreme Court of Pennsylvania had definitely rejected these loose expressions, and, in Hart's Estate (No, I), after expressly repudiating them, surcharged the trustee, who had been granted discretionary powers, on the ground that:

"he has all the knowledge, foresight and judgment of the business man; but the money to invest is not his own but belongs to others; it is his plain duty, if he would safely keep it, to minimize risks. He is not bound to have more prudence than the other, but he must utilize his, in avoiding risks which the one who owes no duties to others is free to take." 15

In 1930, the court analyzed its standard a bit further, allowing fiduciaries to retain investments, when authorized, "unless facts known to them, or which by ordinary watchfulness could have been known to them, rendered the holding of such securities an act of which it is inconceivable that one desiring to do his duty would, in the exercise of 'ordinary good business judgment or foresight,' have been guilty." 16

While the cases do not expressly so state, they indicate that the Pennsylvania court will require that, when the fiduciary, if alert, would receive information which should indicate to him as a person diligently seeking to conserve the estate of another person that the safety of the principal is threatened or that the income is unduly low with respect to a particular investment, he must not make such an investment. Or, if it has already been made, he

Io. Morris v. Wallace, $3 \mathrm{~Pa}$. $3 \mathrm{Ig}$ (I846).

II. Estate of Shields, I4 Phila. 307 (I88I).

I2. Hemphill's Appeal, I8 Pa. 303 (I852) (Stephen Girard, the settlor, had left United States Bank stock to a different beneficiary, Girard College).

I3. Worrell's Appeal, $23 \mathrm{~Pa} .44$ (1854).

I4. Jack's Appeal, 94 Pa. 367 (1880) ; Appeal of Stewart, IIo Pa. 410, 6 Atl. 321 (I885); Bailey's Appeal, I Sadler 398, 5 Atl. 49 (Pa. 1886).

I5. 203 Pa. 480, 485-486, 53 Atl. 364, 366 (1902). See also Taylor's Estate, $277 \mathrm{~Pa}$. 5I8, 529, I2I Atl. 310, 3I3 (I923) ; Brown's Estate, 287 Pa. 499, 50I, I35 Atl. II2, II3 (I926). 16. Linnard's Estate, 299 Pa. 32, 37, I48 Atl. 912, 914 (1930). 
must discontinue it within a reasonable time. ${ }^{17}$ The fiduciary should seek the advice of his attorney, banker, or financial adviser (Moody's, e. g.), for, although not an absolute defense, ${ }^{18}$ such action is evidence of due care and prudence. ${ }^{19}$ Speculation is absolutely indefensible, ${ }^{20}$ as is retention of nonlegals without giving any thought to their disposal. ${ }^{21}$

But these considerations tend only to discover whether an individual investment, standing alone, appears to be safe. Sad experience has taught numerous investors that defaults cannot be predicted by study of the investment independently. Insurance is essential, and most expert investors insure by diversification, which, if not carried to extremes, is unquestionably sound. ${ }^{22}$ Yet one court refused to hold that diversification was part of the duty of care and prudence of the fiduciary, observing that investors differed as to the desirability of diversification, and quoting Andrew Carnegie's motto, "Put all your eggs in one basket and watch the basket." 23 This, however, is too speculative a motto for trust investments. It is not surprising, therefore, that a growing minority, now supported by the American Law Institute, requires that the fiduciary spread his eggs. ${ }^{24}$

Unfortunately, the question whether due care and prudence includes a duty to diversify has seldom appeared before the Pennsylvania courts. As early as I865, nonetheless, a Philadelphia court seemed to approve such a requirement, for, although the court upheld the investment of one-sixth of an estate in obligations of the United States, it is said obiter, "no sane man would invest all in one class of securities." 25 But a recent Montgomery County Orphans' Court case renounces any such legal standard. Although the refusal to surcharge could have been put on other grounds, this court went out of its way to point out that diversification is not a legal standard of conduct for the fiduciary. ${ }^{26}$ Although the question has never been presented

I7. For a view that the standard for continuance of investments is less exacting than for the making of new investments, see Brown's Estate, $287 \mathrm{~Pa}$. 499, 501, I35 Atl. II2, II3 (1926). Logically, the fiduciary should be held to an equally high standard, with an allowance of reasonable time within which to dispose of the non-legals. Proc. Nintr Regional Trust CONF. (I93I) 45; Restatement, Trusts (I935) \$23I.

I8. Lechler's Appeal, ro Sadler 547 (Pa. I888); Grossman's Estate, 22 D. \& C. 53I (I935); 3 Bogert, The Law of Trusts and Trustees (I935) §6I2; McKnNNey, Trust INVESTMENTS (2d ed. I927) 3 I.

I9. 'Jack's Appeal, 94 Pa. 367 (I880) ; see Hammett's Estate, 23 D. \& C. 353, 360 (I935); cf. Detre's Estate, 273 Pa. 34I, II7 Atl. 54 (Ig22). The mere fact that Moody's has stopped rating, or even that the earnings are dropping off, is not enough, however, to hold that the investing fiduciary has failed to employ due care and prudence. Hammett's Estate, supra. But, if the earnings statement shows danger, investment is imprudent. Id. at 360 .

20. Hart's Estate (No. I)

2I. Kelch's Estate, 2I D. \& C. 204 (I934).

22. James G. Smith, Development of Trust Companies in the United States (I928) 427-453; Y. B. AM. BANkers' Ass'N Trust Division (I934-I935) 202 (diversification in retention); Wilson, Standards for Conserving Investments (1935) 6I TRust ConPANIES 7, Io; Woodruff, Legal and Investment Standards of Trustees (1935) 4 FordHaMr I. REv. 39I (an excellent discussion by an investment analyst for the Alexander Hamilton Institute) ; Brookmire Investor, Dec. I4, I935, at 2.

23. Estate of Adriance, 145 Misc. 345, 352, 260 N. Y. Supp. I73, I8r (Surr. Ct. I932).

24. Restatenient, Trusts (I935) \$228. See also Restatement, Trusts (Tent. Draft, I933) $\$ 220$ and explanatory notes thereto.

25. Estate of Naglee, 6 Phila. 28, 29-30 (1865).

26. Elkins' Estate, 20 D. \& C. $483,487-489$ (I934). It is interesting to note here that not only is there a movement toward higher standards for fiduciaries in general, but there is a growing tendency to hold corporate fiduciaries to higher standards than those required of 
squarely to the supreme court of the state, it is hardly likely that this traditionally conservative court will follow the new view. Legislative action would seem highly desirable, therefore.

\section{Sources of Power to Invest}

"Consent, Affirmation, and Release." It seems fundamental that due care and prudence, and even diversification, will not avail the fiduciary if he has no power to make the type of investment he has made. Under our law, this power need not be given by the settlor or the legal list, but may be given by the beneficiaries. According to one writer, who dubs this source of power "consent, affirmation and release", consent, affirmation, release, waiver, approval, acquiescence, estoppel, ratification, and even volenti non fit injuria have been the basis of this defense to surcharge. ${ }^{27}$ The very strong objection to allowing these as a defense to surcharge is that the settlor did not intend it. The very reason for the fiduciary relationship was that the settlor wished to guard the beneficiary against his own imprudence. Allowing the defense permits the substitution for the fiduciary's discretion of the very discretion which the settlor distrusted. Especially is this true with regard to spendthrift trusts, and some courts have balked at going the distance of allowing a "spendthrift" thus to free the trustee of responsibility. ${ }^{26}$ Yet, in Perkins's Trust Estate, the Pennsylvania Supreme Court went so far as to hold, not merely that the spendthrift was barred, but even that the contingent legatees were barred, by the spendthrift's active persuasion that investments be made in realty in which he had a personal interest. ${ }^{29}$

A court which will go to such lengths is, of course, a stronghold for the defense of "consent, affirmation, and release". At one time, however, Pennsylvania was firmly against it. In Nyce's Estate (1843), for example, a trustee was surcharged, even though the cestui que trust's guardian had approved the purchase of United States Bank stock, simply on the guardian's word that he had not intended to assume responsibility. ${ }^{30}$ In Hemphill's Appeal, the next case in which this defense was interposed, it was held that Mrs. Hemphill's acceptance of the dividends on similar stock could have no effect on the judgment. She was not bound to direct the trustees. "The object of their appointment was to protect her against her own imprudence." 31 And in Pray's Appeals (I859), even though there were other grounds on which to predicate surcharge, the court said:

private fiduciaries. One attorney advised his clients, trust company men, that they were held to higher standards, and rightly so. Proc. NInTH Regronal Trust CoNf. (I93I) 45. Zoob, supra note 8 , at $735 \mathrm{n}$, quotes the suggestion of a higher standard because the companies make it their business to administer trusts and hold themselves out as experts. As far as Pennsylvania is concerned, the Supreme Court seemed quite receptive to the idea, but refused to apply it to the case at hand because of the weaknesses in that particular case. Linnard's Estate, 299 Pa. 32, 39, I48 Atl. 9I2, 9I4 (I930).

27. The general discussion of this subject in Zoob, supra note 8, is more than adequate. For a recent discussion of the maxim volenti non fit injuria, see City Bank Farmers Trust Co. v. Smith, 263 N. Y. 292,293 , I89 N. E. 222, 223 (I934).

28. See Zoob, supra note 8 , at 741 .

29. 3I4 Pa. 49, I70 Atl. 255 (I934), citing Curran's Estate, 3I2 Pa. 416, I67 At1. 597

(I933), where appointees of the "content" beneficiary were barred.

30. 5 W. \& S. 254 (Pa. I843).

31. I8 $\mathrm{Pa} .303,307$ (I852). 
"As no power was reserved to these two married women in the will creating the trust, to control or interfere with the investment of the funds, or the management of the estate, their previous request to make the investments, or assent to them afterwards, could not in any degree diminish, alter, or affect, the responsibility of the trustee." $\mathbf{3 2}$

But the last quarter of the nineteenth century brought a period of greater leniency with fiduciaries in Pennsylvania. Perhaps the advocacy of the late and great John G. Johnson is responsible. At any rate, whether to induce men, otherwise deterred, to assume trust duties, or to relieve them from continued harassing by beneficiaries, or to provide a means of flexibility, ${ }^{33}$ the court's attitude changed. In I880 it approved a lower court's holding that the cestuis que trustent were barred by their silent approval for five years, because during this time they could easily have obtained a court order to sell the non-legals. ${ }^{34}$ More recently it refused to surcharge where there was evidence that the beneficiary knew all the details of the investment and yet failed to object. ${ }^{35} A$ fortiori, where the beneficiary requests an investment, ${ }^{38}$ or accepts the dividends with full knowledge of the investment, ${ }^{37}$ or agrees to it in writing, ${ }^{38}$ the court will not surcharge the fiduciary. One cannot predict to what extent it will go. To describe what conduct of the beneficiary may operate to bar him, the court has used various terms: estoppel, ${ }^{39}$ approval, agreement, ratification, contentment, and acquiescence. ${ }^{40}$ No doubt other terms can also be found. The net result is that there is not only a lack of uniformity and accuracy, but there is no dividing line which will indicate what conduct will and what will not bar the beneficiary.

At least greater uniformity and a clearer standard should be attained. If the rule is that the competent and sui juris beneficiary, once he knows of the illegality of the investment, must object to it and must reject the benefits in order that the fiduciary be surchargable, the court should lay down that rule but should also require the fiduciary to inform the beneficiary that this is the necessary procedure. The beneficiary should not be presumed to know

32. $34 \mathrm{~Pa}$. 100, II3-II4 (1859).

33. As to deterrence, see Zoob, supra note 8, at 733. Perkins's Trust Estate is an excellent illustration of annoyance by the beneficiary. On the other hand, the flexibility allowed is obvious. How often the beneficiary's creditors are pressing him, or his mortgage is about to be foreclosed! The objection still remains, however, that the settlor never intended investments such as loans to the cestui que trust. And yet, would he have sat by idly and watched the cestui que tricst's ruin? Limitations are recommended in PROc. NINTH Regional TRUST Conf. (I93I) 46.

34. Coggins' Appeal, 3 Walker 426 ( $\mathrm{Pa}$. r880).

35. Macfarlane's Estate, 317 Pa. 377, I77 Atl. I2 (1935). Contrast Frame's Estate, N. Y. L. J., Dec. 31, I935, at 267I (App. Div. Ist Dep't) :"There is no duty on the part of the beneficiaries to demand that executors dispose of non-legal securities."

36. Perkins's Trust Estate.

37. Macfarlane's Estate, 3I7 Pa. 377, I77 Atl. I2 (I935); O’Brien's Estate, I8 D. \& C. 501 (1933).

38. Armitage's Estate, I95 Pa. 582, 46 Atl. II7 (I900).

39. Perkins's Trust Estate, 314 Pa. 49, 51, I70 Atl. 255, 256 (1934). See also Armitage's Estate, I95 Pa. 582, 587, 46 At1. II7, I22 (I900); Estate of Clermontel, I2 Phila. I39, I4I (1878). Zoob, supra note 8, 735 et seq., severely criticizes this doctrine of estoppel.

40. Coggins' Appeal, 3 Walker 426, 445 ( $\mathrm{Pa}$. r880) (approval); Armitage's Estate, I95 Pa. 582, 588, 46 Atl. 117, I23 (1900) (agreement); Detre's Estate, 273 Pa. 341, 346, II7 At1. 54, 56 (I922) (approval and ratification); Brown's Estate, 287 Pa. 499, 504, I35 Atl. II2, II4 (I926) (agreement); Curran's Estate, 1312 Pa. 416, 424, I67 At1. 597, 599 (I933) (contentment); O'Brien's Estate, I8 D. \& C. 501,502 (I933) (acquiescence); Maser's Estate, 2I D. \& C. 559, 56I (I934) (ratification). Numerous other illustrations may be found. 
the law. A more salutary rule would be to bar the beneficiary only when he, sui juris, competent, and with full knowledge, agrees in advance and in writing to the illegal investment. In such a case, he could more readily be expected to give thought to the matter. Silence and inactivity, or even acceptance of the benefits-often not a matter of choice-indicate no thought about the desirability of the investment. An even more advanced rule would be necessary to approximate the intent of the settlor: total abolition of "consent, affirmation, and release" as a defense. But since this rule might occasionally work a hardship, it should be complemented by a provision that the orphans' or common pleas courts should, upon petition, grant antecedent permission to investment in non-legals provided that the exigencies of the case warrant this extraordinary remedy.

The Intent of the Settlor. Little difficulty is encountered when the settlor clearly indicates what investments shall be made. However, as such an occasion is the exception rather than the rule, difficulties in interpretation ensue.

One source of trouble has been that since the middle of the last century, numerous settlors (usually testators) have provided the fiduciary with discretionary powers. ${ }^{41}$ At first, the Pennsylvania courts were quite prone to find that an expression of discretionary power authorized non-legal investments. One judge, disagreeing with the court for which he was speaking, took the view that the settlor must have expressed a clear intention that the discretion was to extend to the making or continuance of investments. ${ }^{42}$ The present view of the supreme court is this stricter view, and the same dissenting judge is quoted in an oft-cited case, Taylor's Estate:

" "This [the investment in nonlegal securities] may be authorized by the creator of the trust, but where such a provision is relied on, it is for the trustee to establish it with the utmost clearness, and, when shown, it will be strictly construed. . . . The power ought not to be sustained upon conjecture, nor inferred from . . . express grant of discretion as to matters not relating to the management of the [particular] fund [before the court]. The presumption is against the existence of such a power, and all doubts should be resolved against the party asserting it." " 43

Nevertheless, where the settlor indicates with clarity that the fiduciary shall have discretionary power as to investments or that he shall make particular investments, the fiduciary has a definite safeguard, unless the directions are against public policy. ${ }^{44}$ Impolitic directions being rare, however,

4r. Whitaker, The Problem of Legal Investments for Trust Funds (I934) 8 Temp. L. Q. 473,480 .

42. Barker's Estate, I59 Pa. 5I8, 529, 28 At1. 365, 367 (1894).

43. $277 \mathrm{~Pa}$. 5I8, 523-524, I2I Atl. 310, 3II (I923). Accord: In re Safe Deposit Bank of Pottsville, r9 D. \& C. 695 (1933).

44. E. g., where the settlor directs investment in an unlawful business. Nor can the provisions of the Banking Code that prohibit transfer of assets from the commercial departments of trust companies to their trust departments [PA. STat. ANN. (Purdon, 1935) tit. 7, $\$ 8$ I9-IIII] be waived by a settlor's provision that an investment may be made in mortgages, even though not earmarked for trusts when acquired by the company. Investments for Life Insurance Trust, 2I D. \& C. I27 (1934) (Opinion of Deputy Attorney-General Saylor).

But, unless expressly indicated to the contrary, the fiduciary is held to his duty to use due care and prudence, even though he has discretionary powers. Supra p. 642. 
the setting of boundaries to the investing power by the settlor is to be strenuously urged. It is truly fortunate that trust instruments are becoming increasingly instructive. Many are not, though, and in such cases resort must be made to legal investments.

The Common Law. In cases where the settlor had failed to prescribe: investments or to grant discretionary power, the English courts early limited the fiduciary to prescribed classes of investment. At first only government obligations were permitted. Soon afterwards England's foremost property became the basis for an extension of the rule-first mortgages on realty became legal investments. Most American jurisdictions adopted the same rule, but some, like Massachusetts, leader of the "radical minority", relaxed it. Pennsylvania followed the narrower view and, like numerous other jurisdictions, soon enacted statutes on the subject. ${ }^{4 \overline{5}}$

Statutory Investments. In I824 a statute virtually embodying the English rule was enacted, authorizing the orphans' court, upon petition, to direct investment in the debt of the United States, of the Commonwealth, and of the City of Philadelphia, or in real securities. ${ }^{46}$ This rule was periodically expanded, from about 1850 , until it included the obligations of certain other municipalities within the state, and also of the Pennsylvania and Reading Railroads and of the Lehigh Coal and Navigation Company. ${ }^{47}$

Whether or not as a result of this special legislation, Article III, Section 22 of the Constitution of 1873 was adopted, prohibiting the General Assembly from authorizing investment in the bonds or stock of any private corporation. ${ }^{48}$ Ensuing legislation permitted investment in the obligations of the United States, the Commonwealth and its political subdivisions; first mortgages (including participation certificates) on property within the state, not exceeding two-thirds of its fair value; ground rents on domestic property $;^{49}$ and in obligations of the Delaware River Joint Toll Bridge Commission. ${ }^{50}$ Statutes authorizing investment in Joint-Stock Land Bank Bonds and Farm Loan Bonds were, however, unconstitutional in the opinion of the attorney-general, ${ }^{51}$ while a local court declared unconstitutional a law authorizing investment in life insurance, on the ground that this was investment in an obligation inferior even to a bond of a private corporation. ${ }^{52}$ Some of this legislation hearkened back to the days of indiscriminate special legislation.

A very sound extension, the Law of June I7, I9I7, permitted the orphans' court, upon petition, to authorize investment in domestic realty or

45. (I92I) 69 U. OF PA. L. REv. IS9.

46. Pa. Laws I824, c. 24.

47. Trust Investments in Pa. (I935) 9-10.

48. Pa. Const. AnN. (Purdon, 1930) art. III, \$22.

49. Pa. Stat. AnN. (Purdon, r930) tit. 20, \$ \&or.

50. PA. Stat. AnN. (Purdon, I930) tit. $36, \S 340 \mathrm{r}$, art. VII, believed valid by Deputy Attorney-General Saylor. Delaware River Joint Commission Bonds, 2r D. \& C. 566 (I934) (on ground that Commission was not private corporation, and hence constitution did not prohibit).

5I. Joint-Stock Land Bank Bonds as Trust Investments, 4 D. \& C. 55 (1923), on the ground that, since the government did not guarantee the obligations, they were obligations of private corporations. Similarly, in Investment of Trust Funds in Farm Loan Bonds, I9 D. \& C. 287 (1933).

52. Solomon's Petition, 77 Pitts. L. J. 545 (1929), involving Pa. Stat. Ann. (Purdon, I930) tit. 20, \$804. 
in the public debt of other states and municipalities. ${ }^{53}$ Yet few fiduciaries have availed themselves of their right to petition, apparently because of the inconvenience of the procedure.

But many fiduciaries have made borderline investments, producing surprising results. For instance, no credit has been allowed for investments in mortgages on property outside the state, although, by the use of ingenious reasoning, an investment in Camden real estate was upheld. ${ }^{54}$ A corporation's mortgage was upheld as a legal investment, ${ }^{55}$ as were the real 'estate bonds of a "straw man" who actually represented a corporation owning the Shubert Theater, the corporation having assumed the obligation, ${ }^{56}$ despite the objections that these were the obligations of private corporations. Local courts went even farther, one allowing an investment in the stock of a mortgage company, where mortgages underlay the stock, ${ }^{57}$ and another, a twentyyear endowment policy for a minor. ${ }^{58}$

The explanation for these efforts of the state's courts to interpret the constitutional restriction of 1873 broadly is to be found in their sympathy

53. Pa. Stat. AnN. (Purdon, I930) tit. 20, $\$ 804$.

54. Consistency is no attribute of the court. As early as I850, the supreme court had said that it would not authorize investments in places to which its jurisdiction did not extend. Rush's Estate, I2 Pa. 375, 378 ( 1850 ). Similar reasoning supported the result in Trust Estate of Pawnall, 2 Lanc. Bar, no. 47, at I (I87I). The court apparently felt there was some advantage in its jurisdiction over the property in which investments were made, although this attitude has been criticized as mere provincialism. Thus, in Hart's Estate, one of the grounds ,for surcharge was that the investment had been made outside the jurisdiction. Yet the court upheld the investment in Camden realty on the ground that, for business purposes (a far cry from "jurisdiction"), Camden was practically a suburb of Philadelphia. Gouldey's Estate, $201 \mathrm{~Pa}$. 49I, 5I Atl. 3I5 (Ig02). This so-called provincialism is also found in the statutes. Supra note 53 .

55. Maroney's Estate, 3II Pa. 336, I66 At1. 9I4 (1933). The court reasoned that the constitution aimed only at "personal securities", and that the mortgage was actually "real security"; the mere addition of the personal obligation in the form of the corporation's bond should make no difference.

56. Curran's Estate, 3I2 Pa. 4I6, I67 At1. 597 (1933), citing Maroney's Estate, supra note 55 , and holding that, in substance, real security was involved. An early case, Twaddell's Appeal, $5 \mathrm{~Pa}$. 15 ( 1847 ), although not cited by the court, seems to support the results in these two cases. Apparently contra, however, are: Commonwealth ex rel. Algeo v. McConnell, 226 Pa. 244, 75 Atl. 367 (I9I0) ; Huey's Estate, I Chester Co. I70 (I880).

57. In re Duggan's Account, 83 Pitts. L. J. 237 (1935). This, if appealed, will be a difficult case to handle. In Curran's Estate and Maroney's Estate, both supra note 56, the actual investment made by the fiduciary was in a mortgage, or in a bond directly secured by a mortgage, so that the reasoning that they involve real security is not nearly so far fetched as here, where, although the purpose of the corporation is to invest in first mortgages, only the personal security of the corporation is involved. Another objection to allowing the investment is that the fiduciary has delegated his power to invest to the officers of the corporation. This was never intended by the settlor. Iscovitz's Estate, 319 Pa. 277, I79 Atl. 548 (I935); 3 BOGERT, op. cit. supra note I8, at I774.

58. Price's Estate, I9 D. \& C. 266 (I933). Since this arose on petition of the guardian for permission, it is unlikely to be considered by the supreme court, unless the ward, on coming of age, feels injured. The case appears legalistically incorrect in light of the reasoning in Solomon's Petition, sipra note 52, to the effect that this is investment in a personal or corporate obligation. The distinction that an endowment policy is directly for the benefit of the minor, while life insurance is not, is, of course, sound. On the other hand, the cash surrender value of the life insurance policy is ordinarily available to the insured.

The desirability of insurance is, nevertheless, manifest, and the General Assembly no doubt thought so. The validity of the act involved in Solomon's Petition would in all probability, if raised again, not be upheld, in spite of the constitutional amendment of I933. See infra, p. 649. See also FinID, EFFECT OF AN Unconstitutional STATUTE (I935) 288-294 New legislation, pursuant to the amendment, validating investment in insurance, would be highly commendable, therefore. 
for a fiduciary who had to invest and was faced with a narrow list of legal investments, an increasing volume of trust funds, and a natural desire for increased income on the part of beneficiaries. The same situation was responsible for a constitutional change. In addition, the sunshine philosophy of I 929 and the corresponding decrease in purchasing power of those who depended on fixed returns, notably beneficiaries of trusts, rendered the state legislature quite responsive to the amendment proposed by the Pennsylvania Bankers Association. When the proposed change reached the people at the polls, however, gloom had replaced the sunshine, and a campaign of education was necessary to induce the people to approve even a change which would permit the legislature to authorize investment in stocks! Yet the voters carried the amendment, in November, I933, repealing the prior constitutional limitation and providing that the General Assembly might from time to time prescribe investments for fiduciaries. ${ }^{59}$

The Fiduciaries Act of July 2, 1935. No exercise of this new legislative prerogative was attempted until last summer, when the General Assembly passed a bill adopting practically verbatim a proposal of the Pennsylvania Bankers Association. ${ }^{00}$ Apparently no thought was given to the serious problems which have arisen concerning "due care and prudence", and "consent, affirmation, and release". A bare provision to the effect that a fiduciary must use due care and prudence was included, in order that the Act "would, to a certain extent, serve as a code" of trust investment law. ${ }^{61}$ And, although it purports to be a code and includes at least references to nearly all of the other problems, it makes absolutely no reference to the rule that conduct of the beneficiary may prevent surcharge, with the result that at least two vexatious problems remain. ${ }^{62}$

Ostensibly the main purpose of the new law is to provide fiduciaries with a broader list of investments. This is done primarily through the introduction as legal investments of those bonds of railroads, gas, electric, and water companies, and telephone companies, that meet the stringent financial requirements of the Act. ${ }^{63}$ According to a study made by the bankers' association, 278 new securities meet the tests. ${ }^{64}$ Whether such securities should have been made proper types of investment for fiduciaries is a disputed matter. Some experts would limit investments to government obligations; others feel that the new law is sufficiently conservative ${ }^{65}$ still others suggest that different standards should be employed; ${ }^{66}$ and a number would be even bolder and invest in equities. ${ }^{67}$ " In view of this divergence of opinion, the question

59. PA. Const. ANN. (Purdon, I935) art. III, §22. For a history of its enactment, see TrUST InVEstarents IN PA. (I935) I3-I4.

6o. Cf. pamphlet, Proposed Statutory Limitations on Trust Investments, issued by the bankers' association in 1935, with PA. Stat. AnN. (Purdon, 1935) tit. 20, \$ 801.

6r. PA. Stat. Ann. (Purdon, I935) tit. 20, \$80I (13) (a). See Trust Investaments IN PA. (1935) 33.

62. Perhaps the inclusion in the new act of provisions respecting "consent, etc.," would have been unwise, since the latter problem is not confined to the field of investment. A separate act might be preferable.

63. Pa. Stat. ANN. (Purdon, I935) tit. 20, § 801, 8-10.

64. TRUST InVESTMENTS IN PA. (I935) 38-57.

65. Y. B. BANkERs' Ass'N TRUST Drvision (I934-r935) 8I; (I935) 6I Trust CoMrPANIES I2.

66. Wilson, sitpra note 22 , at I2.

67. Symposium on the Future Trend of Living Costs (I935) 6I Trust Companies 25 et seg., wherein outstanding economists predict a rise in the price level, and recommend equities, diversification, and constant revision of investment portfolios. 
was properly one for the legislature. What is regrettable is that the legislature gave this important matter of policy no attention on the floor. In the light of the stringent financial limitations imposed, of the urgent necessity for more types of legal investment, and of the period of relative prosperity generally thought to be in the offing, the extension that has been made cannot be considered radical. Had the legislature openly debated the desirability and possibility of conserving purchasing power in an inflationary period, artificial or otherwise, they might have deemed it not too radical to allow investment in stocks conforming to stringent standards. ${ }^{68}$ Additional diversification could thus have been facilitated. The refusal to make such an extension would not, however, be surprising even had it been considered.

While there has been this extension into utility bonds, government securities, if not extended, have been re-defined. Under the new law they include any obligations for the payment of interest and principal on which the faith and credit of the United States, the Commonwealth, or its political subdivisions are pledged. ${ }^{69}$ Various "New Deal" obligations are thereby included, notably mortgages guaranteed by the Federal Housing Administration and debentures of the FHA. Separate subsections specifically including FHA obligations ${ }^{70}$ would, therefore, appear superfluous, as the sponsors of the bill recognized. ${ }^{71}$ As to the advisability of including government securities in the portfolios of fiduciaries, there is practically no dissent among experts, notwithstanding threats of artificial inflation and increasingly unbalanced budgets. ${ }^{72}$ One defect in this section of the new law, however, lies in the specific provision for the housing obligations, in that it may have the effect of leading the courts to interpret the more general provisions very narrowly. Too often is the legislative intent thus misconstrued. If government obligations remain as sound as in the past, however, this undesired result will in all probability not materialize.

Real securities have been definitely restricted by the new law. ${ }^{73}$ Only "improved real estate" may now be security for investments. There was a further proposal to exclude all "single purpose properties", 74 but the legislature finally determined that only theaters and manufacturing premises should, like unimproved real estate, be taboo. Yet the law apparently provides a loophole whereby theaters and factories may be security for legal investments, for the restriction can be found only in Subsection 6 of the law which provides that investment may be made in real estate bonds, "secured by improved real estate . . . not . . . used as a theatre or for manufacturing purposes." Another subsection which provides that the fiduciary may

68. Apparently the legislature gave little thought to such a possibility, or, in fact, to the possibility of any changes in the bill as introduced. The Legislative Journal discloses no discussion on the floors of either the Senate or the House, although the committees must have given the bill serious consideration. The only amendment of importance to be proposed, however, was that referred to infra note 74. For a history of the bill, see HISTORY of House BiLls and Resolutions (1935) 50.

69. Pa. Stat. Ann. (Purdon, 1935) tit. 20, § 8or (2-3).

70. Id., Ir, $\mathrm{I2}$.

7I. Trust Investments in PA. (1935) 32-33.

72. Nor is the yield on government securities substantially lower than that on other forms of high grade bonds. (1935) 60 Trust CoMPPANIES I7o.

73. Pa. Stat. Ann. (Purdon, I935) tit. 20, §80I (4-6).

74. An amendment proposing to exclude also garages, stables, dance halls, houses of amusement, and houses of worship, was struck out. (I935) I8 LeGrsLatrve Journal 4465, 4466 . 
invest in first mortgages, securing bonds or other obligations, limits them only to "improved real estate . . . situated within this Commonwealth". Evasion of the legislative purpose through participations ${ }^{75}$ in mortgages on the forbidden realty will, therefore, be difficult, if not impossible, to prevent. Another new limitation is on ground rents. These must now, when capitalized at five per cent, total no more than two-thirds of the fair value of the property, although prior to the new law, the two-thirds limitation was imposed only on mortgages and real estate bonds. While in general real securities are subject to criticism because of the recent history of real estate and because of the inherent difficulties of liquidation, the new restrictions imposed by the Fiduciaries Act should provide the necessary safety.

The new section entitled "Fractional Interests" in effect allows investment in any portion of any whole investment legalized by the Act. ${ }^{76}$ In it may be found several changes from the earlier provisions on participations. The most striking is the omission of the earlier prohibition against holders of deeds of trust for which real estate bonds are issued relieving themselves of their ordinary duties as trustees by contracting to that effect with purchasers of the bonds. This practice, which has been the subject of severe criticism in this REVIEw, ${ }^{77}$ is once more legalized by the omission, doubtless deliberate though not even referred to by the sponsors. The new Act also dispenses with the necessity for a trust certificate-the bankers appeared particularly anxious for this change, ${ }^{78}$ which can seem to have no advantage other than savings in the expense of printing and duplicating the certificates. And yet the advantage of a trust certificate, in that its issue is strong evidence of a definite appropriation to the trust, would seem far to outweigh the expense entailed. Serious attention should be given to restoring the earlier requirements.

The severest criticism of the new Act is not, however, related to the types of investment made legal, ${ }^{79}$ nor even to omissions referred to, but to two features of the Act which are, paradoxically, at once too stern and too lenient with the fiduciary. The first is that the qualifying requirements of the utility bonds newly admitted are so technical that the ordinary fiduciary, especially the private fiduciary, will be unable personally to make safe selections. To invest in railroad bonds, for example, the fiduciary must determine, inter alia, whether the railroad is not a street railroad, what its domestic mileage is, its operating revenue, its voting stock, its total stock outstanding and fully paid, the ratio between its fixed and its remaining obligations, the population of some of the municipalities through which the railroad runs, and whether there have been defaults within the past six years. ${ }^{80}$ And not only

75. Pa. Stat. AnN. (Purdon, I935) tit. 20, §80I (7), entitled "Fractional Interests" is the new provision on participations.

76. Ibid.

77. Gouley, Real Estate Mortgage Bonds as Trust Investments (1935) 83 U. of PA. L. REv. 953,960 et seq.

78. Trust Investarents in PA. (I935) 22-23.

79. As to the advantages and disadvantages of real estate bonds, see Gouley, sitpra

80. Pa. Stat. ANN. (Purdon, I935) tit. 20, §80I (8). "Shortcomings of some of these tests, such as those relating to minimum mileage, gross income, percentage of dividends over a stated period, and the ratio of the mortgage to the underlying property" have been pointed out, and other criteria for soundness suggested. (1935) 60 TRUST CoMrpanIES I72.

The Committee on Trust Investments of the Pennsylvania Bankers' Association reported to the banks and trust companies in the state in I934: "Those to whom this pamphlet is 
is such an investigation necessary upon making the investment, but, since an investment which ceases to fulfill the requirements must be discontinued, ${ }^{81}$ constant study is necessary. To be sure, the fiduciary could seek the advice of an expert, but that would be no defense in itself. ${ }^{82}$ The hardship on the corporate fiduciary, however, is not so great, for he is better equipped to determine these technical matters, and one investigation will suffice him for all of the numerous trusts he administers. While this might be the very basis for arguing that corporate fiduciaries should be preferred in appointment and that the special hardship on the individual fiduciary should therefore not be considered, there are, doubtless, occasions where a private person can because of his intimacy with the settlor and the beneficiaries better serve them.

In New York, the situation is ameliorated by the publication of a list of named securities thought to fall within the qualifications of the statute. ${ }^{83}$ Since both the private and corporate fiduciary would benefit, the General Assembly should act promptly to direct the Secretary of Banking to prepare a similar list for Pennsylvania. The economies that would result from having his department determine for all fiduciaries within the state what investments are legal, although private study would still be necessary, would manifestly be great, for the fiduciary's search would be limited. The legislature should also consider the novel proposition that investments made in securities enumerated in the published list ${ }^{84}$ should not be surchargeable. Such tenderness for fiduciaries, however, should be accompanied by the imposition of strict duties of watchfulness and diversification.

The leniency in the law lies in its opening words: ". . . a fiduciary . . . may invest in" the obligations that follow. ${ }^{85}$ The dogma has it that a statute reading "shall" or "must" is mandatory and exclusive, and that the fiduciary will be surcharged for any investment outside the statute, whereas a statute reading "may" invest is permissive, and the fiduciary may be cred. ited even for investments outside the statute. ${ }^{86}$ The cases involving earlier Pennsylvania legislation on the subject are confusing ${ }^{87}$ which is the explanation for the discord of writers. Some classify Pennsylvania according to the dogma, but one writer thought that Hemphill's Appeal ${ }^{88}$ had settled the

addressed are requested to read this bill sympathetically with an appreciative understanding of the object to be attained [strengthening of the administration of trusts in the state]. The proposed legislation may seem to be complicated, but this is a technical subject in which it is not possible to prescribe proper tests in few words." Even corporate fiduciaries were expected to object to the technical study necessitated.

8I. Pa. Stat. Ann. (Purdon, I935) tit. 20, §80r, I3c.

82. Supra p. 643.

83. Such a list is periodically published by the State Superintendent of Banks of New York. See e. g. (1934) 59 TRUST CoMpanIEs 657-658. The bankers had originally planned a companion bill to the new Fiduciaries Act. This bill was to require the Banking Department to promulgate a legal list, but was "temporarily dropped" because "the passage of that bill would have involved an extra burden upon the office of the Secretary of Banking." (I935) 6r Trust Companies 63I.

84. See Woodruff, supra note 22,413 et seq., for a suggestion that investments be controlled by a commission.

85. Pa. Stat. Ann. (Purdon, I935) tit. 20, §80I.

86. 3 BogerT, op. cit. supra note I8, § 6I4. See also Gibson's Estate, 3I2 Pa. 359, 362, I67 At1. 282, 283 (I933) (decision expressly on ground that no loss had been sustained).

87. Whitaker, supra note $4 \mathrm{I}, 474-478$.

88. I8 Pa. 303 (I852). 
problem and that "may" had finally come to mean "must" in Pennsylvania. ${ }^{89}$ Yet the Common Pleas Court of Philadelphia recently held that the constitutional provision of 1873 did not prohibit the court from authorizing investment in corporate stocks, ${ }^{90}$ although a federal court had interpreted the Pennsylvania Constitution as an absolute prohibition of any transaction in stocks by fiduciaries. ${ }^{91}$ The confusion has continued, and the retention of the old form of words is, therefore, unfortunate. Not too bold is the view that the explanation lies in the fiduciaries' desire for another loophole through which surcharge may be evaded. While a permissive statute would seem to be of little value, the legislature ought at least to have expressly provided either that it was to be permissive or that it was to be mandatory. This ambiguity should be promptly remedied.

\section{Conclusion}

While the new law does indeed impose salutary limitations on investments that may be made for beneficiaries, it reflects to a large extent, like the laws of other jurisdictions, the natural inclination of fiduciaries, particularly of trust companies, to seek legislation that will primarily favor them. ${ }^{92}$ Indirectly, of course, lenity with the fiduciaries may result in profit to the beneficiaries, since it will enable the fiduciary to offer his services at lower rates. But this can, of course, be carried too far, and beneficiaries should be protected by the imposition of higher legal standards on fiduciaries.

Nor should legislation which involves such a great stake be hastily considered by the legislators. The people, and consequently the government, have a deep interest in the billions held by fiduciaries in Pennsylvania. The legislature has been given constitutional power to protect this interest. Impending summer-time is no excuse for hurried exercise of this power which results in technical errors, unexplained changes, and unforeseen preferences. ${ }^{93}$ It is to be hoped that the legislature, spurred by a keener public interest, will study the possibilities of clarifying the existing law as to investments, raising investment standards, and reducing to a minimum technical errors which may result in serious injury to both large and small interests which combine to form a vast proportion of the assets in the state.

\section{E. I. C.}

89. Whitaker, supra note $4 \mathrm{I}, 478$. Yet 3 BoGERT, op. cit supra note $18, \S 6 \mathrm{I}_{4}$, cites later Pennsylvania cases for the opposite proposition. Darlington's Estate, $245 \mathrm{~Pa}$. 212, 91 Atl. 486 (I9I4), is often incorrectly cited. The trustee's attorney had stolen non-legal securities in which the trustee had invested without authority. The trustee not having been negligent in his control of the securities, he was not surcharged. The case can stand only for the rule that where the loss does not occur from default or depreciation in the investment, there is no surcharge.

90, Reibel's Estate, 23 D. \& C. 307 (I935).

9I. Bagnell v. Ives, I84 Fed. 466 (C. C. M. D. Pa. IgII).

92. I9 REP. OF STATE BAR AsS'N OF WIS. (I929) 18.

93. The Fiduciaries Act is not the only instance of legislation jammed through the last session. See Note (I935) 84 U. OF PA. L. REv. 84. 